\title{
Como o Big Brother Brasil 20 arquitetou a sua comunicação a fim de potencializar os acontecimentos imprevisíveis do programa ao vivo? ${ }^{1}$
}

Maria Eduarda Vasconcellos Becker Garibe

Pontifícia Universidade Católica do Rio de Janeiro - PUC-Rio

Departamento de Comunicação Social - Bacharelado em Publicidade

\section{RESUMO}

Este presente trabalho se propõe a investigar como a comunicação do reality show, Big Brother Brasil 20, foi arquitetada a fim de potencializar os acontecimentos imprevisíveis do ao vivo. O estudo aborda os diferentes componentes da comunicação transmidiática, suas características e outros aspectos que contribuíram para expor da melhor maneira o conteúdo que estava sendo produzido a cada minuto dentro da casa. Além de pontuar diversos fatores que contribuíram para o sucesso da transmissão, tratando da mudança nos hábitos de consumo de conteúdo e a interatividade entre o emissor e receptor.

\section{PALAVRAS-CHAVE:}

Reality show; Comunicação transmidiática; Hábitos de consumo; Big Brother Brasil; Engajamento;

\section{Introdução}

Programar a comunicação de um reality show não é uma tarefa fácil, e fazer dela um recurso decisivo para o seu sucesso e engajamento com o público é ainda mais difícil. 0 Big Brother Brasil teve a sua maior edição no ano de 2020, depois de ter sido transmitido mais de dezenove vezes ao longo de dezoito anos. Por isso, o tema deste artigo coloca em pauta a estrutura da comunicação transmídia do BBB20, utilizando a mídia tradicional e as redes sociais como os principais veículos de conteúdo. Mais a fundo, será analisado: Como o BBB20 arquitetou a sua comunicação a fim de potencializar os acontecimentos imprevisíveis do programa ao vivo?

No país, o BBB 20 ressignificou o entretenimento, servindo como um meio de escape da realidade, durante um período pandêmico. A comoção, interatividade e a influência são o que tornaram o Big Brother Brasil 20 um programa a ser estudado. Sua volatilidade,

\footnotetext{
${ }^{1}$ Artigo derivado de monografia de graduação em Publicidade, orientada pela professora Bárbara Assumpção e apresentada em dezembro de 2020.
} 
capacidade de reformulação a partir das novas tecnologias, faz dele um gigante do entretenimento. Estudar sobre a arquitetura da sua comunicação é entender como a comunicação transmídia está sendo usada nos dias de hoje em seu primor. É entender como um movimento unitário, foi criado no país, em momento de crise, a partir de um único programa de entretenimento.

Por fim, tem-se como objetivo traçar os passos da comunicação transmídia do programa ao vivo e entender o seu funcionamento e a importância que teve para o sucesso da vigésima edição. Ainda se tem como foco, analisar o relacionamento de três dos principais veículos de comunicação do programa: o programa ao vivo na Rede Globo, a conta do BBB na rede social Twitter e o portal oficial na internet, GShow.

\section{O Reality Show como gênero propício à convergência entre mídia tradicional e rede social e mudança nos hábitos de consumo de conteúdo.}

Desde o começo do programa, a internet e a tevê sempre se cruzavam. Os produtores entenderam a experiência vivenciada por cada usuário das redes, e tentaram usar esta descoberta a favor do aumento do engajamento do programa. Nas redes sociais, mesmo estando sempre conectado a uma rede de pessoas, interagindo no mesmo meio e ao mesmo tempo, a experiência era particular. É "uma nova forma social de comunicação maciça, mas produzida, recebida e vivenciada individualmente" (CASTELLS, 2011 apud PUGNALONI, 2015). Hoje, o BBB é um dos programas que mais incorporam essa nova forma de consumo de conteúdo entre a mídia tradicional e as redes sociais. Sua estrutura e forma trazem ao público uma interação e receptividade de conteúdo fora do comum.

Yvana Fechine, explora essa relação entre os traços e características da internet encontrados no modelo do BBB, exibido na Rede Globo. Em seu estudo, ela explica como toda a estrutura e formatação do programa é feita para que o público tenha a possibilidade de interação e identificação.

Há quem associe a intensificação desse comportamento voyeurista do público à prática inaugurada pela internet do uso de webcams por meio dos quais usuários permitem que os outros acompanhem o seu cotidiano on-line [...] o êxito deste formato pode ser explicado, também porque ele manifesta uma forma cultural que opera uma síntese de características da internet e da televisão, sendo, por isso, propensa para esse momento de transição de modelos na TV. (FECHINE, 2009,p.157) 
Fechine fala da relevância deste formato no momento de transição dos modelos tradicionais vistos na televisão. A comunicadora Luiza de Mello Stefano, cita Fechine e reforça o que foi exposto. Ela explora a importância de gerar reconhecimento na programação, apresentando conteúdos que possam ser associados ao cotidiano do telespectador. Isso faz com que o público possa ter mais curiosidade com que está sendo retratado.

[...] os reality shows trazem dois componentes muito procurados pela sociedade: a curiosidade em querer saber o que se passa na vida das pessoas, na maioria das vezes, pessoas comuns como o telespectador, e a satisfação de ter essa curiosidade sanada; e a espetacularização das práticas simples do dia a dia, que são transformados em grandes momentos pela mídia [isso] cria uma espécie de identificação por parte dos telespectadores, que escolhem aqueles que mais gostam para proteger e até mesmo perceberem nas atitudes dos participantes uma forma de autoconhecimento. O diferencial deste gênero na televisão está ligado ao conteúdo, feito por fatos reais, sentimentos humanizados e que trata de questões e problemas do cotidiano. (STEFANO, 2016, p.29)

Com o passar das edições, o programa foi se moldando cada vez mais às novas tecnologias e plataformas de comunicação. A convergência entre mídia tradicional, representada pelo programa Big Brother Brasil, e as novas mídias, entre elas as redes sociais e às plataformas audiovisuais, evoluiu muito. O programa ganhou mais audiência e engajamento do público na medida que a convergência foi ficando mais nítida (STEFANO, 2016). A vigésima edição, usada como objeto desta pesquisa, mostra claramente esta evolução. As novas mídias trouxeram "um dos grandes apelos do BBB, a possibilidade do público interferir diretamente no programa, passando a consumir uma narrativa cujo desenvolvimento depende também da sua atuação" (FECHINE, 2013, p.157). A introdução da segunda tela funciona como uma extensão da mídia principal, neste caso a exibição do programa na Rede Globo. Ela traz novos conteúdos e permite a interação em tempo real do público.

A segunda tela se refere à interação paralela da experiência do usuário com o conteúdo da televisão e dos dispositivos móveis, possibilitando novas formas de participação e engajamento da audiência. Enquanto ele assiste a primeira tela (geralmente a televisão), o mesmo interage simultaneamente com uma tela adicional (dispositivos móveis). (STEFANO, 2016, p.35)

Hoje, o Big Brother Brasil utiliza diversas mídias para construir a sua cadeia transmidiática de conteúdo. A sua segunda tela está aumentando, cada vez mais possibilitando novas 
formas de interação. O Twitter $^{2}$ e o Instagram $^{3}$ são as suas redes sociais principais utilizadas para replicar conteúdos publicados na íntegra no Globoplay e no GShow.

Durante muito tempo, a indústria televisiva enxergou as redes sociais como ferramenta auxiliar, utilizava as plataformas como já eram usadas, não havia grandes inovações no tipo de conteúdo e como ele era passado. Sobretudo, era um relacionamento distante, com uma divisão clara entre os dois meios. O sociólogo Pierre Lévy, identifica este conceito como uma polarização entre uma mídia assimilada ao poder (TV) e uma mídia individual (Redes Sociais), e dá como solução para uma comunicação melhor, a ideia de "uma identidade em rede com mais inteligência coletiva e transparência" (LEVY, 2013 apud PUGNALONI, 2015).

No momento em que há o entendimento de uma nova ferramenta, em que TV e Redes funcionam integradas em uma só comunicação, temos o que impulsiona a mídia de hoje: convergência e conexão.

A convergência representa uma transformação cultural, à medida que consumidores são incentivados a procurar novas informações e fazer conexões em meio a conteúdos midiáticos dispersos. (...) Por haver mais informações sobre determinado assunto do que alguém possa guardar na cabeça, há um incentivo extra para que conversemos entre nós sobre a mídia que consumimos. Essas conversas geram um burburinho cada vez mais valorizado pelo mercado das mídias. O consumo se tornou um processo coletivo (...) (JENKINS, 2009, p.30).

Levando em consideração os aspectos mencionados acima, podemos dizer que o reality show é um dos gêneros televisivos que mais incorpora e coloca em prática a ideia de que a convergência de mídia é muito maior do que uma bilateral. Não é uma dicotomia entre tevê e redes sociais, mas a junção entre os meios, formando uma comunicação transmidiática. Logo, o objetivo é maximizar a comunicação e potencializar o conteúdo, usando diferentes canais para transmitir a mensagem. Henry Jenkins define esta narrativa como "uma nova estética que surgiu em resposta à convergência das mídias - uma estética que faz novas exigências aos consumidores e depende da participação ativa de comunidades de conhecimento" (JENKINS, 2009, p.49).

É de extrema valia significar a comunicação transmídia para darmos continuidade ao

\footnotetext{
2 Rede social que simula um blog pessoal, oferecendo um espaço de 280 caracteres para você publicar mensagens para seus seguidores.

3 Rede social online de compartilhamento de fotos e vídeos.
} 
trabalho. Deste modo, Bruno Scartozzoni nos explica que a comunicação transmídia "conta uma história por meio de diferentes mídias, tendo consciência de que cada uma exige uma narrativa específica e atinge públicos diferentes" (SCARTOZZONI, 2013). Contudo, vamos nos ater mais a fundo ao que é comunicação transmídia, mais à frente.

Com a presença cada vez mais marcante das redes sociais, a barreira de interação entre o consumidor e o emissor foi afastada de vez. Uma esfera dinâmica, que traz um consumidor conectado e integrado com o emissor. Deparando-se com um novo tipo de comportamento de consumo e rapidez na disseminação de informação, a televisão se reinventa mais uma vez para tentar acompanhar a conexão e interatividade tidas como eixo central das redes. "Bem-vindo à cultura da convergência, onde as velhas e novas mídias colidem, onde mídia corporativa e mídia alternativa se cruzam, onde o poder do produtor de mídia e o poder do consumidor interagem de maneiras imprevisíveis" (JENKINS, 2009, p.29). Logo, o objetivo é simples: potencializar a comunicação e seu alcance através das múltiplas plataformas e meios existentes.

Ao entender a essência da comunicação e como as necessidades e o comportamento de consumo se moldaram nos últimos anos, temos como resultado maior engajamento e interatividade do usuário com o meio. Não é entender que há um novo método de se comunicar, mas, sim, entender que se colocou em pauta uma nova ferramenta, que entende a essência da comunicação e tem mais força e facilidade de potencializá-la. "É um contraste com as noções mais antigas sobre a passividade dos espectadores nos meios de comunicação" (JENKINS, 2009, p.30).

\section{Trocando o molde}

Neste ano, por usar a narrativa transmídia e planejar sua comunicação de forma única, sem pensar a televisão e as redes como meios distantes, o Big Brother Brasil 20 se tornou o reality show com maior interação do mundo. A vigésima temporada foi exibida pela Rede Globo de 21 de janeiro a 27 de abril de 2020, 4 dias a mais do programado decorrente a pedidos constantes do público. Ela foi a maior e mais influente; em termos de votos, compartilhamentos, influência, engajamento e cobertura midiática. Isso porque ela conseguiu juntar estratégias de emissão de conteúdo na televisão aberta e cenário online integralmente. Entrando para a história e batendo recordes no Guinness World Records como a maior votação do programa e de reality shows no mundo com 1.532.944.337 
bilhão de votos. (GSHOW, 2020). Além disso, de acordo com um levantamento da ComScore ${ }^{4}$ publicado em um artigo pela revista Metrópoles, "nos primeiros dois meses do programa [...] o BBB20 movimentou, nas redes sociais, 55 milhões de ações (likes, cliques e compartilhamentos), cerca de $916 \mathrm{mil}$ por dia. Tornando a conta do reality a mais relevante digitalmente $[\ldots]^{\prime \prime}$ (METRÓPOLIS, 2020)

A comunicação escolhida fez uso de diversas redes sociais como Twitter e Instagram, plataformas de interação e serviços de streaming da própria emissora como o Globo Play e o GShow. Em consequência, uma rede de troca de conteúdo foi formada, além de ser alimentada, de hora em hora, pelo canal com informações novas, era fomentada a todo segundo pelos telespectadores e internautas.

Diariamente, diversos conteúdos eram transmitidos para o público, sempre tendo em vista a comunicação transmídia e as melhores ferramentas dentro de cada plataforma. Além de permear por diversas redes, a programação na TV também era potencializada usando diversos canais como forma de continuar a transmissão.

A diferença, entre a edição de 2019 e o sucesso da comunicação do BBB20, pode ser resumida em poucas palavras: elo entre comoção e interação. Ao repensar a relação entre essas duas potências, trazidas respectivamente pela mídia tradicional e redes sociais, o programa conseguiu criar uma comunicação transmídia ininterrupta. As informações passadas na TV e nas redes sociais se complementavam, mas eram apresentadas de maneira inteligente, fazendo com que uma não seja incompleta sem a outra.

Assim sendo, cheguei a um ponto, após diversas análises, concluindo que a comunicação transmidiática do programa funciona através de um tripé de plataformas. Deste modo, cada uma age para que a comunicação entre o emissor e o receptor seja potencializada e feita de maneira ininterrupta criando assim a fusão entre comoção e engajamento. Este fator será explorado a fundo um pouco mais a frente, mas fica explícito que neste tripé, o programa o vivo na Rede Globo trata a comoção, a rede social Twitter o engajamento e o portal do GShow atua como um ponto de encontro entre as plataformas.

O BBB20 repensou, e por isso ressignificou, o que é ter audiência do século XXI. Com a otimização da sua comunicação na vigésima edição, o programa reconfigurou o seu

\footnotetext{
${ }^{4}$ ComScore é uma empresa americana que fornece a grandes empresas e agências de publicidade análise de dados de internet.
} 
público ativo. Quem engaja e participa do programa não é somente mais aquele telespectador que vê a edição na íntegra todos os dias, mas aquele que acompanha através das redes sociais e aquele que vota em um paredão sem sequer ter visto um episódio, mas que foi influenciado por um post que viu nas redes sociais. A cada minuto, novos conteúdos sobre o que estava acontecendo dentro da casa eram postados na conta do Twitter do Big Brother, usando a \#BBB para que o conteúdo mencionado fosse associado a outros do mesmo assunto. Desta forma, mesmo os que não acompanhavam o programa saberiam dos acontecimentos do programa involuntariamente, pois o assunto entrava na barra de assuntos mais falados na rede.

O público ativo do programa aumentou significativamente. O que antes eram apenas espectadores da Rede Globo e fãs do reality, virou internautas que acompanhavam o programa indiretamente, por meio das redes sociais, pessoas que twittavam ${ }^{5}$ sobre os barracos entre os participantes sem sequer saber o nome de quem estava envolvido. 0 BBB20 tomou uma proporção jamais vista antes em reality shows, e o melhor era que eram seguidores ativos e novos interessados, ou seja, a melhor fórmula para gerar engajamento e interação.

Reconfigurar o seu público ativo deu ao BBB a possibilidade de se tornar o maior de todos, na sua vigésima edição. Quando não tinha mais o que inovar, sua comunicação foi polida e aperfeiçoada, abraçando ainda mais os internautas, e tornando o público um dos produtores mais influentes do programa.

Dito isso, para ter uma análise clara dos fatores que influenciaram o sucesso desta edição, é necessário contextualizar o cenário em que o país se encontrava, enquanto o programa estava no ar, assim como a influência e o poder que cada mídia usada na cadeia transmidiática possui sobre a massa.

\section{Contexto e Influência social - Famosos e a pandemia}

É engraçado dizer que o programa se tronou o que é por interação orgânica, pois ela é completamente planejada para ser orgânica, é uma ambiguidade sem fim. Um dos motivos pelos quais esse tipo de interação veio à tona foi através dos influenciadores que fizeram parte do programa. O BBB20 estreou com uma novidade, a presença de famosos

\footnotetext{
${ }^{5}$ Verbo que significa, escrever e publicar um Tweet (mensagem) na rede social Twitter.
} 
no elenco.

Enfim, os participantes do Big Brother Brasil 20 foram anunciados. Este ano, além de Brothers anônimos, a casa mais vigiada do Brasil contará com a presença de personalidades famosas, entre elas a cantora Manu Gavassi e a influenciadora digital Bianca Andrade [...]. Como de praxe, a $20^{a}$ edição do reality show terá 18 participantes, mas o jogo será dividido meio a meio. As celebridades ficarão no grupo Camarote, enquanto as pessoas desconhecidas do grande público farão parte do time Pipoca. (METRÓPOLIS, 2020)

O elenco de famosos foi composto por personalidades da internet, atores, cantores, blogueiras e atletas. Alguns com bastante reconhecimento do público e outros com menos. Diversos dos influenciadores que entraram na casa mais vigiada do Brasil prepararam estratégias individuais de marketing para ajudar a impulsionar a sua visibilidade na casa. Naturalmente, além de ajudá-los no crescimento das suas contas, eles trouxeram ao programa a interação dos seus seguidores. Isso criou uma convergência de mídia, fazendo com que os diversos nichos presentes entre os seus seguidores conhecessem e fizessem parte do público ativo do programa.

As influenciadoras que entraram na $20^{a}$ edição do Big Brother Brasil continuam ativas nas redes sociais mesmo durante o confinamento e deixaram estratégias de marketing alinhadas para ganhar ainda mais seguidores. Se a Manu Gavassi lançou um clipe em dia de paredão, Bianca Andrade não ficou para trás. A influenciadora de maquiagem deixou uma equipe de nove pessoas cuidando de sua imagem fora da casa e conteúdo pronto para as redes sociais para os três meses. (O GLOBO, 2020)

Todos os conteúdos produzidos pelas influenciadoras levavam à hashtag do programa, \#BBB20, seja o conteúdo publicado no Twitter ou em outra rede social. Isso fazia com que o nome do programa, e a hashtag que o simbolizava, ficasse divulgado com grande recorrência, disseminando ainda mais a imagem do BBB. A influência social que estes personagens têm sobre o público e o engajamento que eles trazem conseguem, antes mesmo de participar do programa, são pontos decisivos, quando explicamos a interação como diferencial do BBB20. O peso das redes sociais e o local propício ao rápido compartilhamento fizeram com que desde o começo da edição o programa já fosse muito comentado nas plataformas digitais. Os seguidores que acompanhavam as publicações na internet durante o dia eram convergidos a assistir ao personagem à noite, nas telas da Rede Globo.

Comenta-se, com frequência, a respeito do impacto do COVID-19 nos hábitos de consumo da população. Com o Big Brother Brasil 20 não foi diferente. A presença de uma pandemia 
de escala global seria definitivamente um fator decisivo para garantir o sucesso ou fracasso do programa. Felizmente o impacto na vigésima edição foi positivo.

De acordo com o Ministério da Saúde brasileiros, os corona vírus são uma grande família de vírus com grande capacidade de transmissão de pessoa para pessoa. A taxa de transmissão foi tão alta que a Organização Mundial de Saúde (OMS) declarou estado pandêmico, acarretando a implicação de quarentena em diversos países. Com a quarentena, diversas pessoas que tinham uma rotina de trabalho durante o dia ficaram com tempo ocioso. As emissoras tiveram que parar de produzir seus conteúdos, novelas saíram do ar e programas de entretenimento pararam de ser exibidos. O Big Brother Brasil 20 foi o único programa de entretenimento da Rede Globo que não parou.

Concordo que a edição seja chamada de 'histórica' pelas diversas circunstâncias que a cercam, em especial o fato de ter sido o único programa de entretenimento da Globo ao vivo durante parte da quarentena, pela participação, pela primeira vez, de convidados famosos, e pelo resultado em termos de audiência, engajamento e números recordes de votos nos paredões. (PRISCO, 2020)

"No caso da TV, o papel mais importante que ela cumpre como mídia decorre da possibilidade de construir a realidade por meio da representação que faz [...]" (MARTINS, 2015). O BB20 durante alguns meses de quarentena foi capaz de dar ao telespectador, por menor que seja, uma sensação de realidade em meio de uma pandemia. O programa conseguiu alavancar ainda mais a sua audiência e participar da vida de milhares de pessoas diariamente.

\section{Contemplando o tripé}

Uma vez apresentado os componentes críticos do tripé de comunicação, chega a hora de examinar como ele exerce a sua função na prática. Para facilitar a compreensão, o diagrama abaixo mostra a relação entre as partes.

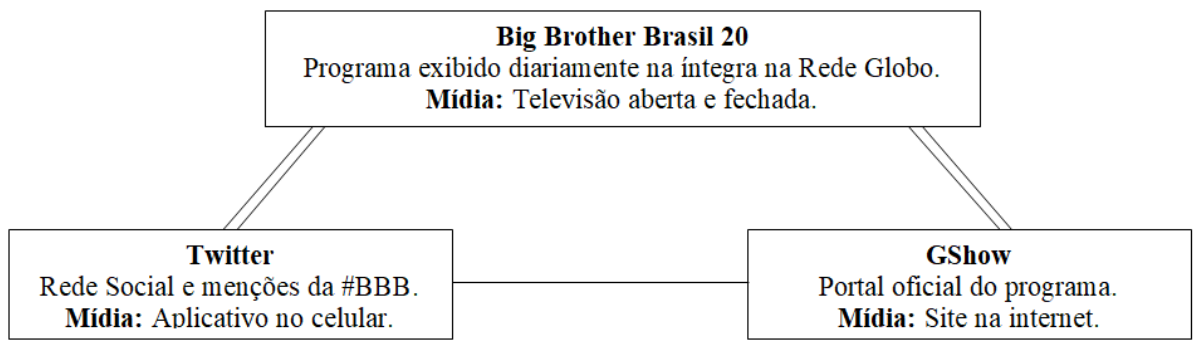

DIAGRAMA 1 - Tripé de Comunicação 
As conexões duplas entre as caixas mostram uma interatividade mais forte e recorrente, em comparação com a conexão singular. Logo, o contato entre o programa exibido na integra, com o Twitter e a plataforma GShow é maior e mais frequente do que o contato entre o Twitter e o GShow. Esta relação entre os componentes é feita de maneira que eles interajam em uma comunicação sem costuras e remendas. Esta é realizada da seguinte forma: o programa ao vivo traz a comoção e capta o público pelo espaço que ocupa e pela mídia em que é exibido. A rede social trata do engajamento e atua como um local de manifestação dos fãs. Por último, o portal oficial opera como uma ponte entre o digital extremo (aplicativo do Twitter) e a mídia de costume do telespectador, a tevê. Além de agir como um local de informação constante e confiável, uma vez em que a plataforma que habita é mais conhecida e navegada pelo público do que um aplicativo.

É importante entendermos que, além de serem três espaços diferentes, cada um se manifesta em um dispositivo alternativo. O Twitter é mais acessado por meio do aplicativo no celular, o GShow através do site no computador e o programa ao vivo é exibido e visto na televisão. Deste modo, o telespectador recebe conteúdos variados de um único programa em plataformas distintas. Da mesma forma, é de extrema valia entender até que ponto o emissor tem controle da informação que é consumida pelo receptor. O veículo pode até transmitir o conteúdo, mas ele depende de diversos fatores para que essa informação chegue até o seu consumidor. Entre elas, podemos mencionar: o tipo de conteúdo buscado, a capacidade de interação de quem usa a plataforma e a habilidade de atualização com novas tecnologias (MAVEN, 2018).

O tripé é harmônico na sua funcionalidade, mas não é equilibrado. Como dito anteriormente, a relação entre as partes tem forças distintas. Com base nos programas assistidos, em minha análise, existem recursos de comunicação presentes ao longo dos episódios na Rede Globo, que atuam como agentes potencializadores dos acontecimentos ao vivo. Estes recursos são lançados através da fala do apresentador e de textos na tela da televisão. Os mesmos agem como meio, utilizados para induzir o telespectador a tomar uma ação específica, além de fortalecerem a comoção, a interação e o engajamento presentes nas mídias da cadeia de comunicação. Do mesmo modo em que existem agentes potencializadores de comunicação do programa na íntegra, o Twitter e o portal do GShow também utilizam alguns recursos chave. 


\section{Programa ao vivo na Rede Globo}

O BBB é exposto na maior e mais influente emissora do país, que tem um papel de construção de pensamento societário grande. O principal conteúdo do programa é apresentado neste meio, mostrando a vida de anônimos no maior palco da televisão brasileira. Para potencializar os acontecimentos de dentro da casa, alguns recursos são usados com recorrência nos programas ao vivo. São eles: a comunicação estratégica do apresentador com o público; os comentários e hashtags do Twitter presentes nos episódios da íntegra; e as chamadas constantes para o portal GShow. Apenas com esta pequena demonstração já começamos a entender que todas as plataformas/mídias usadas para comunicar os acontecimentos do BBB20 com o público são interligadas.

No caso do programa, o apresentador Tiago Leifert traz vida, emoção e ajuda mais a classificar o reality show como um jogo de realidade. Seu jeito de fala, as expressões usadas e modo de apresentação de Leifert conduzem e influenciam o programa e o telespectador, a fim de propiciar engajamento.

Diversos recursos são usados pela emissora a fim de mandar/enviar os telespectadores para outras plataformas de conteúdo. Um deles é o call to action ${ }^{6}$, termo em inglês que traduzido para o português significa chamada para ação. É uma ferramenta muito usada em sites, e-mails e anúncios que indica ao usuário o que deve ser feito. Muitas vezes o CTA (Call to Action) explora termos no imperativo como "clique", "siga" e "acesse". Um exemplo seria o uso das palavras "vote lá", "você continua votando", "escolha" em paralelo com a divulgação constante do link do GShow, o apresentador utiliza o CTA para enviar o público que está assistindo o programa na televisão para o portal do GShow na internet. O telespectador sai da mídia tradicional e é convergido a uma mídia secundária, tendo a oportunidade de explorar mais conteúdo do programa e contribuir com a votação. Deste modo, a comunicação entre o ao vivo e o GShow vai sendo construída através da televisão e a comunicação transmidiática se mostra presente mais uma vez.

O GShow emprega a função de local de votação para paredões, provas do líder, enquetes e mais, além de promover uma interatividade direta com o público do programa. Por ser um portal oficial na internet, traz mais peso e confiabilidade do que uma rede social, fazendo com que o público o procure para informações oficiais. Por fim, ele é o meio pelo

\footnotetext{
${ }^{6}$ Call to Action é um termo em inglês que traduzido para o português significa chamada para ação. É uma ferramenta muito usada em sites, e-mails e anúncios que indica ao usuário o que deve ser feito. Muitas vezes o CTA (Call to Action) explora termos no imperativo como "clique", "siga" e "acesse".
} 
qual o público age como o terceiro produtor, decidindo fatores importantes do programa e ajudando a dar sequência na trama.

A conexão do programa na íntegra com o Twitter também é uma que se faz clara e é presente em diversos momentos durante a transmissão. Os comentários ao vivo dos internautas são exibidos simultaneamente durante a exibição do BBB20. A rede social e os comentários feitos pelos usuários são colocados na tela, com o nome e o tweet, além das hashtags \#RedeBBB e \#BBB20. Essa ação age como um estímulo para engajamento. O estímulo é dado ao público que está assistindo, instigando a vontade de participar do acontecimento, entrar na rede social e comentar sobre o programa para tentar aparecer na televisão. No programa do dia 06 de fevereiro de 2020, os tweets se encontram presentes na tela quinze vezes durante a transmissão, e neles as hashtags aparecem mais uma vez.

Após ficar no ar quatro dias a mais do que previsto, o último programa da temporada foi marcante quando falamos dos recursos usados para compor a comunicação transmídia. Em uma hora e dez minutos de transmissão ao vivo. Dos recursos já mencionados, vale a pena ressaltar que, durante este programa, exibido no dia 27 de abril de 2020, o link para o portal GShow foi falado e apontado na tela 6 vezes, sendo também o último gráfico na tela no final do programa antes do logotipo da emissora. A \#RedeBBB permeou o programa por inteiro, sendo escrito e falado por diversas vezes durante a transmissão. $O$ Twitter teve uma grande influência neste episódio. Memes ${ }^{7}$, momentos marcantes, gírias, expressões e hashtags provindos da rede social, que atua como local de manifestação dos fãs foram usados para rebobinar toda a trama da temporada.

\section{0 Twitter}

Durante todo o programa o Twitter se comportou de maneira a ajudar na repercussão do programa atuando como: local de manifestação dos fãs; local de contato mais próximo dos fãs com uma plataforma do programa; local de engajamento e repercussão dos acontecimentos; e local propulsão e convergência para o GShow e programa ao vivo. Como na televisão, estes recursos atuaram de maneira a potencializar os acontecimentos do ao vivo, propulsionando a comoção, interação e engajamento.

\footnotetext{
7 Memes são informações que viralizam na rede, sendo compartilhada diversas vezes. São conteúdos imagéticos ou de vídeo, na maioria das vezes engraçados.
} 
A plataforma atuou como local principal de manifestação dos fãs, onde a linguagem usada pela a conta do BBB na plataforma se igualava ao jeito e linguajar usado pelos usuários e fanáticos do programa. O Twitter proporcionou aos que acompanhavam de perto os episódios, memes, $\mathrm{GIFs}^{8}$ e assuntos para serem comentados, curtidos e engajados.

Um recurso usado neste meio é o de publicar comentários sobre a edição no Twitter enquanto o programa ao vivo está no ar, tornando a experiência de assistir ao novo episódio coletiva e compartilhada.
A pesquisa realizou uma comparação ano a ano, e descobriu que $25 \%$ dos telespectadores relataram tomar conhecimento da grade de programação através das redes sociais. [...]15\% dos entrevistados disseram que gostam mais de assistir televisão quando as mídias sociais estão envolvidas. E a televisão tem cada vez mais investido no telespectador internauta, promovendo hashtags, exibindo comentários, criando espaços específicos para determinados programas. (CANALTECH, 2020)

Os comentários feitos na rede social sobre o programa ao vivo enquanto ele está sendo transmitido na Rede Globo, atua como um CTA, "mandando" os usuários para o portal GShow para conferir trechos do episódio que acabou de ir ao ar na Rede Globo. Isso faz com que a informação tenha mais tempo de uso e se não se torne obsoleta tão rapidamente, além de proporcionar a chance de ser vista por outras pessoas que não acompanham o programa pela a sua mídia principal, mas sim pelas redes sociais.

Essa possibilidade de engajamento e de aumento do público ativo do programa é sem dúvidas um dos pontos que atribuíram ao programa a sua capacidade de viralização. Isso fica bem claro quando pegamos exemplos de momentos marcantes do programa como o paredão histórico de um bilhão de votos. Por ser uma ocasião que tinham grande potencial de repercussão, a conta na rede fez questão de ajudar na propulsão deste conteúdo, postando e reforçando diversas vezes durante a transmissão o conteúdo que tinha acabado de ser compartilhado com o telespectador. Durante o paredão histórico, o seguinte tweet foi ao ar:

O tweet abaixo representa com extrema clareza a comunicação transmídia e o tripé. O post foi publicado durante a exibição do BBB20 na Globo, com a \#RedeBBB que fica presente na tela da televisão a todo instante. Além de comentar sobre o que havia acabado de ser informado na televisão e proporcionar o ato de compartilhamento do conteúdo na

\footnotetext{
8 "O GIF é um formato de imagem que pode compactar várias cenas e com isso exibir movimentos" (HOSTGATOR, 2018)
} 
rede, ele também age como uma mídia de convergência para o GShow, encorajando os usuários a participarem da votação que está acontecendo no momento.

Big Brother Brasil @ @bbb · Mar 31

MAIS DE 1 BILHÃO DE VOTOS NO PAREDÃO! E É isso mesmo que você leu: U M BILHÃ O! \#BBBilhão Já entramos para a história com o recorde de votação, e a vitória é de vocês!

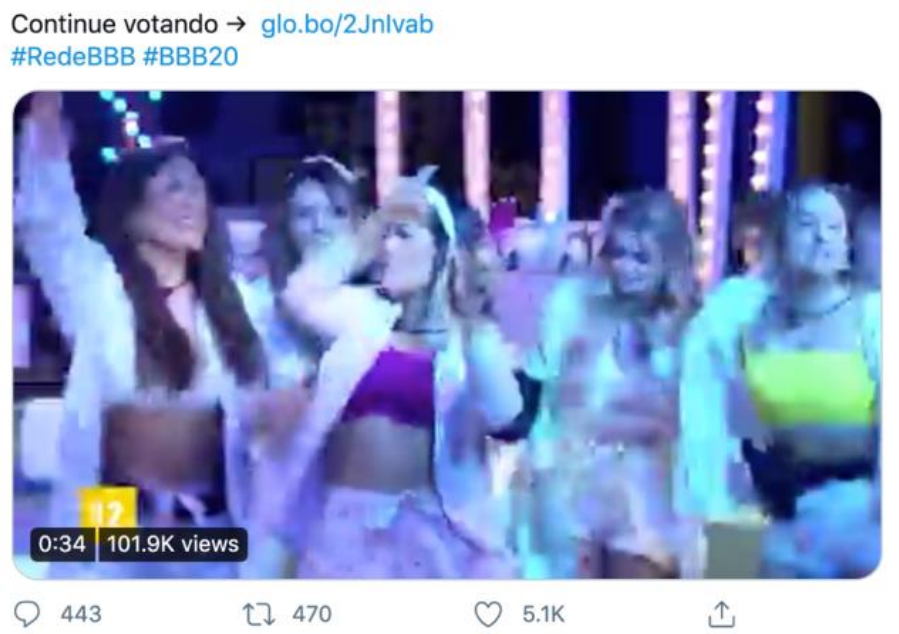

FIGURA 1: Exemplo de Tweet com link para o GShow, publicado na conta oficial @BBB Fonte: Twitter Oficial BBB

\section{O GShow}

O portal GShow utiliza dois recursos para potencializar o conteúdo ao vivo. Entre eles, a constante atualização dos acontecimentos de dentro da casa e a hospedagem de todas as votações do programa. Por ser o espaço que repercute todos os acontecimentos da casa em primeira mão para o público que não tem acesso a transmissão ao vivo da casa $24 \mathrm{~h}$, ou seja, a grande massa, o portal se torna uma das únicas maneiras de ter contato direto com as informações de dentro durante o dia, enquanto esperam o programa na íntegra a noite. O GShow age como a plataforma central de informação do Big Brother, alimentado as outras redes, como o Twitter, com informações para serem compartilhadas, multiplicando assim os canais em que a informação é veiculada. Sendo assim, ele age como uma ponte, integrando as diversas plataformas que convergem o público para ele.

Durante o período de 04 de fevereiro de 2020 a 06 de fevereiro de 2020, mais de 20 atualizações foram feitas no portal por dia para que os telespectadores pudessem 
acompanhar o dia-a-dia dos participantes. Informações sobre o andamento da casa, acontecimentos durante o dia e conversa dos participantes foram publicadas, dando informação do que acontece dentro do reality para quem está fora.

Além das atualizações escritas, ele também atua como uma plataforma host de vídeos e clipes do dia-a-dia da casa e trechos do programa na íntegra, para os "não assinantes" da plataforma, disponibilizando cliques do dia para atualizar os internautas. Outro recurso importante do portal é o fato de ser o assegurador de todas as votações e enquetes do programa. O GShow hospedou todas as votações do programa, assim como enquetes para as provas, festas e outros momentos de decisões importantes e interação direta com o público. Desta forma, é importante reforçar o fato de o portal ser a plataforma com mais conexão direta com o público em momentos decisivos. É através dele que eles podem se expressar e dar a sua opinião, é por este veículo que eles agem mais uma vez como o terceiro produtor do programa.

\section{Considerações finais}

Chegamos ao fim, e depois de ter assistido toda à temporada novamente e analisado todos os instantes e compartilhamentos feitos pela produção do programa ficou mais claro para mim como o Big Brother Brasil 20 arquitetou a sua comunicação a fim de potencializar os acontecimentos ao vivo.

O sucesso da estratégia do BBB20 se deu através da comunicação transmídia, usando veículos propícios a melhor recepção de conteúdo pelo público. Cada meio potencializou os elementos chave da trama desta edição. Organizados em um tripé, os veículos habilitaram todo o potencial de cada acontecimento dentro da casa, fazendo com que ele fosse compartilhado e engajado por milhares de pessoas em plataformas distintas.

Uma comunicação sem costuras e remendas, com cada plataforma agindo de maneira a explorar suas melhores características. O programa ao vivo trazia a comoção, captando o público pelo espaço que ocupa e pela mídia em que é exibido. A rede social tratava do engajamento, atuando como um local de manifestação dos fãs. Por último, o portal oficial operava como uma ponte entre o digital extremo (aplicativo do Twitter) e a mídia de costume do telespectador, a tevê. 
Alguns outros fatores que contribuíram e facilitaram para que a comunicação pudesse ser potencializada são o gênero propício a convergência de mídia e a mudança de hábitos de consumo de conteúdo, elevando a interatividade entre o emissor e o receptor.

A reformulação da estratégia de consumo e emissão de conteúdo do BBB20 ajudaram a alavancar uma trama com personagens selecionados a dedo. A integração de famosos no elenco, anteriormente formado somente por anônimos, atuou como uma ferramenta essencial para o aumento do público ativo e da interação orgânica.

Cada veículo de comunicação usado nesta edição trouxe características importantes para potencializar os acontecimentos do ao vivo. Ao fim, fica claro como a comunicação do BBB20 foi arquitetada, mas alguns questionamentos vêm à tona.

Será que ter uma comunicação bem arquitetada, com componentes potencializadores, vai continuar sendo o bastante para gerar engajamento parecido nas próximas edições? Ou fatores externos, como a pandemia do COVID-19, tiveram um papel no sucesso da trama maior do que podemos enxergar neste momento? Além disso, que outros elementos da produção do programa, podem exercer papel decisivo na hora de contar os acontecimentos imprevisíveis com maior impacto?

Estes são alguns dos questionamentos que coloco em pauta e deixo em aberto para futuras pesquisas sobre o tema.

Que melhor jeito de encerar esta jornada, senão com o discurso feito por Tiago Leifert nos últimos minutos de uma temporada histórica para as três finalistas do BBB20? Faço dele as minhas palavras, se encaixando perfeitamente com tudo o que foi discutido nestas páginas.

Temporada histórica é sim. Algumas pessoas dizem que foi a melhor de todos os tempos [...] E foi por vários motivos, teve de tudo! Teve competição, emoção, humor, fogo no parquinho, romance, romance platônico também, Casa de Vidro, Quarto Branco, um elenco repleto de possíveis campeões e campeãs. A gente falou de assuntos muito importantes aqui dentro, assuntos sérios, e foi bonito porque esse elenco estava muito equipado para falar desses assuntos; a gente conseguiu falar com leveza e com inteligência de assuntos muito difíceis. E aí veio o confinamento, não o de vocês, o nosso. Vocês vão encontrar um mundo muito diferente meninas daquele que vocês deixaram. O BBB ocupou um espaço na vida das pessoas que a gente jamais imaginou que iria ocupar; porque sem futebol, o BBB virou a competição. As pessoas gritaram nas janelas e varandas torcendo por vocês e pelo nosso 
elenco, em um bate e volta, em uma prova do líder. Sem festa? A festa era a festa do BBB. E aqui fora sem abraço e sem beijo, era quando a gente olhava vocês se abraçando e se beijando que a gente sabia que tudo ia ficar bem, e a gente olhava e falava, puxa, como a nossa vida é boa, como a nossa vida era legal antes, mas que vai ficar tudo bem também. (REALITY SHOW, BBB, 2020)

\section{Referências Bibliográficas}

BIG Brother Brasil. GShow, 2020. Disponível em:

<https://gshow.globo.com/realities/bbb/>. Acesso em: 21 de maio de 2020.

BRENNER, Saullo. NARDELLI, Bruna. MORAES, Felipe. Manu Gavassi, Boca Rosa, Pyong Lee...Conheça os famosos do BBB20. Metrópoles, 2020. Disponível em: $<$ https://www.metropoles.com/entretenimento/bbb/manu-gavassi-boca-rosa-pyong-leeconheca-os-famosos-do-bbb20>. Acesso em: 29 de outubro de 2020.

CANALTECH. Estudo mostra como as redes sociais têm influenciado a televisão. Redação CanalTech, 2020. Disponível em: <https://canaltech.com.br/redes-sociais/Estudomostra-como-as-redes-sociais-tem-influenciado-a-televisao/>. Acesso em 10 de dezembro de 2020.

COMSCORE. Wikipédia, 2020.2 Disponível em: <https://pt.wikipedia.org/wiki/ComScore>. Acesso em: 29 de outubro de 2020.

ESTRATÉGIA de marketing: Bianca Andrade deixou fotos e vídeos gravados para os três meses de BBB20. O GLOBO, 2020. Disponível em: $<$ https://oglobo.globo.com/ela/gente/estrategia-de-marketing-bianca-andrade-deixoufotos-videos-gravados-para-os-tres-meses-de-bbb20-24219945>. Acesso em: 29 de outubro de 2020.

FECHINE, Yvana. A programação da TV no Cenário de Digitalização dos Meios: configurações que Emergem dos Reality Shows. In: FREIRE FILHO, João. A TV em transição: tendências de programação no Brasil e no mundo. Porto Alegre: Sulina, 2009. FECHINE, Yvana. Televisão transmídia: conceituações em torno de novas estratégias e práticas internacionais da TV. Em: XXII Encontro Anual da Compós. Salvador, 2013. HOSTGATOR. O que são GIFs e como usá-los na estratégia de comunicação da sua empresa. Hostgator, 2018. Disponível em: <https://www.hostgator.com.br/blog/o-quesao-gifs-e-como-usar/>. Acesso em: 08 de dezembro de 2020.

JENKINS, Henry. Cultura da Convergência. Edição: Nova Edição - Ampliada e atualizada. Rio de Janeiro, 2009.

MARTINS, Andréia. Comunicação - Rede Globo, sinônimo de televisão no Brasil? UOL, 2015. Disponível em: <https://vestibular.uol.com.br/resumo-das- 
disciplinas/atualidades/comunicacao-rede-globo-sinonimo-de-televisao-no-brasil.htm>. Acesso em: 28 de outubro de 2020.

MAVEN. VEJA 7 diferenças entre leitores de jornais impresso e online. Maven, 2018. Disponível em: <https://www.maven.com.br/blog/veja-7-diferencas-entre-leitores-dejornal-impresso-e-online/>. Acesso em: 9 de dezembro de 2020.

PRISCO, Luiz. BBB20: números mostram que este foi o maior BBB da história. Metrópoles, 2020. Disponível em: < https://www.metropoles.com/entretenimento/bbb/bbb20-numeros-mostram-que-estefoi-o-maior-bbb-da-historia>. Acesso em: 30 de outubro de 2020.

PUGNALONI, Clara. Comunicação para o desenvolvimento, redes sociais, rebeliões e cobertura midiática. Dissertação (Dissertação em Comunicação e Artes) - Universidade de São Paulo. São Paulo, 2015.

REALITY SHOW. Big Brother Brasil 20. Rio de Janeiro: Rede Globo, 27 de abril, 2020. Programa de TV.

RECORDE de votação: BBB20 tem mais de 1,5 bilhão de votos no décimo paredão. GShow, 2020. Disponível em:

<https://gshow.globo.com/realities/bbb/bbb20/casa-bbb/noticia/recorde-de-votacaobbb20-te m-mais-de-15-bilhao-de-votos-no-decimo-paredao.ghtml>. Acesso em: 5 de maio de 2020.

SCARTOZZONI, Bruno. Strorytelling e Transmídia: afinal, o que é e pra que serve?. Profissional de E-Commerce, 2013. Disponível em:

$<$ https://www.profissionaldeecommerce.com.br/storytelling-e-transmidia-afinal-o-quee-e-par a-que-serve/ >. Acesso em: 4 de outubro de 2020.

SIQUEIRA, André. Call to action: tudo o que você precisa saber sobre CTA. Resultados Digitais, 2020. Disponível em: <https://resultadosdigitais.com.br/blog/tudo-sobre-callto-action/>. Acesso em: 29 de outubro de 2020.

SOBRE a doença. Ministério da Saúde, 2020. Disponível em: <https://coronavirus.saude.gov.br/sobre-a-doenca>. Acesso em: 28 de outubro de 2020 STEFANO, Luiza de Mello. Convergência Midiática e Segunda Tela: uma análise das plataformas online do Big Brother Brasil. Universidade Federal de Juiz de Fora, Minas Gerais, 2016.

STEIN, Thaís. O que são memes? Dicionário Popular, 2019. Disponível em: <https://www.dicionariopopular.com/meme/>. Acesso em: 09 de dezembro de 2020. TIRE todas suas dúvidas sobre o que é Twitter. MLabs, 2021. Disponível em: <https://www.mlabs.com.br/blog/twitter/>. Acesso em: 17 de maio de 2021. 